\title{
護床工からの土砂の抜け出しに及ぼす 変動水圧の影響に関する研究

\author{
EFFECT OF WATER PRESSURE VARIATION ON \\ SAND REMOVAL FROM BED PROTECTION WORKS
}

\author{
前野詩朗 $^{1} \cdot$ 山縣正明 $^{2} \cdot$ 里本公明 $^{3}$ \\ Shiro MAENO, Masaaki YAMAGATA and Kimiaki SATOMOTO \\ 1 正会員 工博 岡山大学助教授 環境理工学部噮境デザイン工学科（テ 700-8530 岡山市津島中 3-1-1） \\ 2 学生会員 岡山大学大学院 自然科学研究科環境システム学専攻（广 700-8530 岡山市津島中 3-1-1） \\ ${ }^{3}$ 正会員 岡山大学技官 環境理工学部噮境デザイン工学科（テ 700-8530 岡山市津島中 3-1-1）
}

\begin{abstract}
The bed protection works around the hydraulic structures like dam and bridge piers are usually collapsed due to disasters of sinking into the sand and transporting of sands around its bed protection works specially during flood flow. Disasters of protection works are declined the function and the stability of important hydraulic structures, and they are the factors of utterly destruction of the hydraulic structures. So, it is very important problem in hydraulic engineering to clarify destruction mechanisms of bed protection works and to propose disaster prevention measure.

In this study, we take up the phenomenon of sand removal from bed protection works considered to be a main cause of disasters. To examine such a phenomenon, an experimental flume model was used to conduct a set of experiments subjected to water pressure variation. The experimental results found good to be able to explain the effect of water pressure variation.
\end{abstract}

Key Words : bed protection works, water pressure variation, local scouring, liquefaction

\section{1.はじめに}

高度成長期の砂防施設の整備や河川改修の結果, 河川 への流出土砂量が減少し, 全国的各地の河川において河 床低下が深刻な問題となっている. このような状況下に おいて，堰や橋脚などを保護する目的で設置される護床 工が洪水時に沈下散乱するといった被害が多く見られる ようになってきた. 写真-1は堰下流部の被災状況を示し ている.このような護床工の被災は，堰や橋脚などの重 要な河川構造物の機能・安定性を低下させるのみなら ず，構造物そのものの壊隇的な破壊の要因となるため, 護床工の被災機構を明らかにし, 被災防止策を提示する ことは水工学上重要な課題である.

以上のような背景のもと, 代表的な水理構造物である 円柱橋脚周辺の局所洗掘を取り扱つた研究が多くなされ てきた(例えば, 鈴木 ${ }^{1}$ ), 辻本 $\left.{ }^{2}\right)$ ). 本研究で対象として いる護床工の安定性を検討した研究としては, 中川ら が護床工からの砂の抜け出しによる空洞化の進行過程を 明らかにした研究や, 神田ら゙)が護床工様式の違いが護 床工下流部の最大洗掘深位置や底面せん断力に及ぼす影 響を明らかにした研究などがある. しかし，これらの研 究は殆どが水理構造物周辺の流れ場と河床材料のせん断 抵抗力との関係により現象を捉えた研究であった.

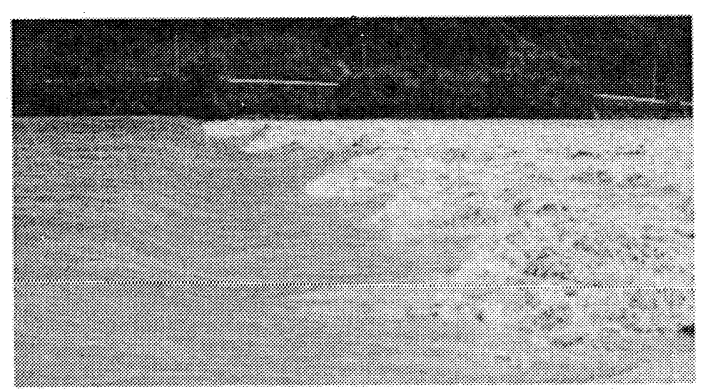

（a）洪水時の状况（昍川合同堰, 平成10 年台風 10 号)

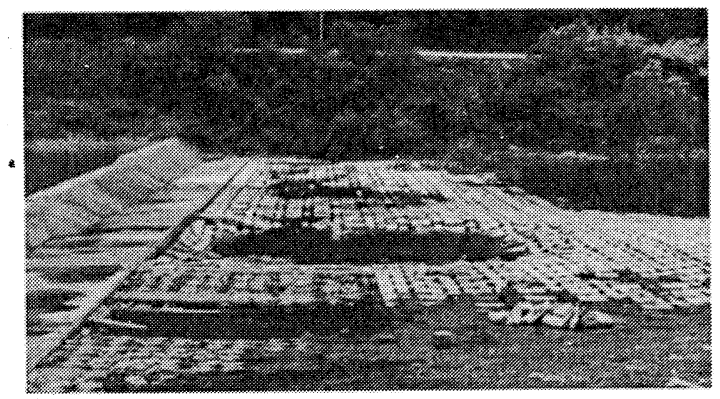

(b) 同地点の被災状況

写真 -1 洪水前後の状況

一方, 名合 ${ }^{5)}$ は水理構造物周辺に作用する急変流が水 圧変動として構造物周辺砂地盤に作用し, 砂地盤内の間 隙水圧を変化させることにより砂地盤の有効応力が減少 


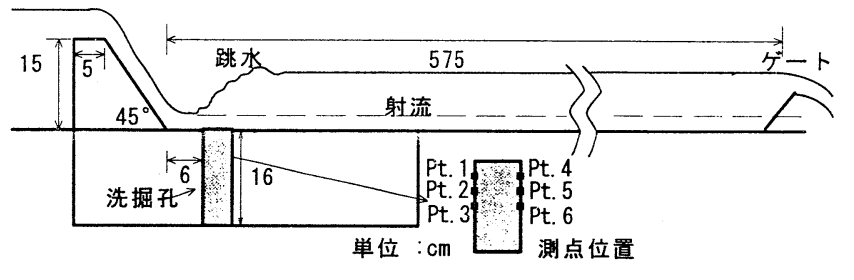

図 -1 実験装置

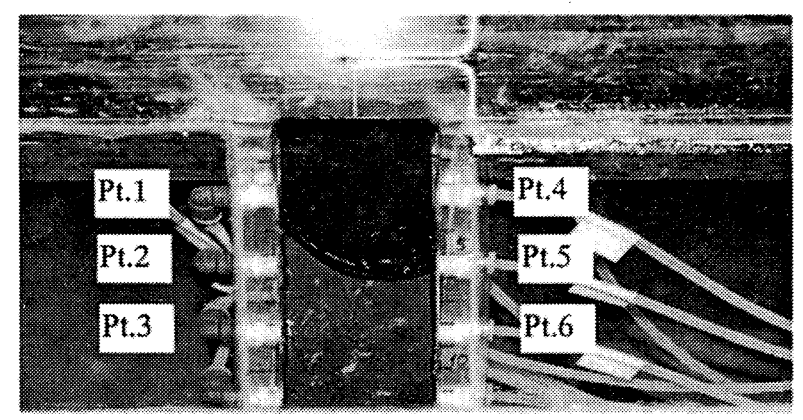

写真 -2 圧力変換機の取り付け状況

し,極端な場合には液状化が発生することを明らかにし ている.また,このように液状化した砂層では, 水平方向の 流れにより洗掘が容易に進むことを指摘している.その 後, 名合 ${ }^{6}$ ) やMaeno ら ${ }^{7)}$ は変動水圧の夕が作用する場に おいて護岸裏込め土砂の流出により護岸裏込め部の空洞 化が発生することや護床ブロック下部の砂の側方流動に よりブロックの沈下が発生することを実験により明らか にしている.実際の流れ場において変動水圧の影響を検討 した研究としては, $\mathrm{Mia} 5^{8)}$ が急激な水圧低下時の円柱橋 脚周辺の局所洗掘に及ぼす液状化の影響を明らかにして いる. また, 村上ら9) は透過性防護工からの砂粒の抜け出 しに及ぼす圧力変動の影響を検討し,圧力変動を外力とし た砂粒の離脱推定法を提案し実験值と良く一致すること を示しているが, 害際の間隙水圧変動は計測されていな い.このように実際の流れ場における変動水圧と洗掘との 関係を取り扱った研究例は非常に少なく,洗掘に及ぼす変 動水圧の影響は詳細には明らかにされていない.また, 跳 水の有無による变動水圧の挙動の相違を扱った研究は, これまでのところ行なわれていないようである.そこで, 本研究は護床工の被災の主な原因と考えられる護床工か らの土砂の抜け出し現象に着目し,現象に及ぼす変動水圧 の影響を明らかにしようとするものである.以上の目的を 達成するために, 本研究では堰下流部における護床工から の土砂の抜け出し現象をモデル化した洗掘孔を堰下流部 に設置した実験を行い, 土砂の抜け出し現象之変動水圧と の関係を実験的に検討する.

\section{2. 実験の概要}

\section{（1）実験装置}

本実験に用いた水路は, 長さ $16 \mathrm{~m}$, 幅 $0.6 \mathrm{~m}$, 深さ $0.4 \mathrm{~m}$ の 水平水路で, 洗掘孔より上流部 $6 \mathrm{~cm}$ の位置に堰を設置し
表 -1 実験条件

\begin{tabular}{|c|c|c|c|}
\hline Case & 流量 (1/s) & \multicolumn{2}{|c|}{ 状態 } \\
\hline $1-a-1$ & 29.9 & 土砂 & $\begin{array}{l}\text { 無 } \\
\end{array}$ \\
\hline $1-a-2$ & 30.0 & 土砂 & 無 \\
\hline $1-b-1$ & 30.0 & 洗掘 & 無 \\
\hline $1-b-2$ & 29.9 & 洗掘 & 無 \\
\hline $1-c-1$ & 29.9 & 洗掘 & 有 \\
\hline $1-c-2$ & 29.9 & 洗掘 & 有 \\
\hline $2-a-1$ & 29.9 & 土砂 & $\begin{array}{l}\text { 無 } \\
\end{array}$ \\
\hline $2-a-2$ & 29.9 & 土砂 & $\begin{array}{l}\text { 無 } \\
\end{array}$ \\
\hline $2-b-1$ & 30.0 & 洗掘 & $\begin{array}{l}\text { 無 } \\
\end{array}$ \\
\hline $2-b-2$ & 30.0 & 洗掘 & 無 \\
\hline $2-c-1$ & 30.0 & 洗掘 & 有 \\
\hline $2-c-2$ & 30.0 & 洗掘 & 有 \\
\hline $1-c-3$ & 20.0 & 洗搐 & 有 \\
\hline $1-c-4$ & 29.9 & 洗掘 & 有 \\
\hline $1-c-5$ & 40.0 & 洗挴 & 有 \\
\hline $2-c-3$ & 19.9 & 洗婳 & 有 \\
\hline $2-c-4$ & 30.0 & 洗掘 & 有 \\
\hline $2-c-5$ & 40.0 & 洗掘 & 有 \\
\hline
\end{tabular}

ている. 水路の下流部にはゲートを設置しており跳水を 生起させる位置を調節することができる. 図-1 に示すよ うに，洗掘孔として $16 \mathrm{~cm} \times 5 \mathrm{~cm} \times 5 \mathrm{~cm}$ のアクリル製の 角柱を洗掘の状況が可視化できるように水路右側のガラ ス面に添わせて設置した. 間隙水圧の計測のため, 図-1 の測点位置に示すように洗掘孔の上流側と下流側の面に それぞれ上から順に $3 \mathrm{~cm}, 6 \mathrm{~cm}, 9 \mathrm{~cm}$ のケ所, および洗掘 孔の中心位置と等しい水路中央部の河床面に圧力変換器 を取り付けた(写真-2). また, 洗掘孔上の水位変動を計 測するために容量式波高計を設置した. 砂試料としては, 平均粒径 $0.25 \mathrm{~mm}$, 比重 2.65 の豊浦標準砂を使用した.

\section{（2）実験方法およで実験条件}

本実験では, 土砂の河床面からの離脱外力に影響する と考えられる鉛直方向の変動水圧を, 跳水による水面変 動で与えることとし, 洗掘孔より下流側に跳水が生起す る場合をCase1, 図-1 に示すように洗掘孔上に跳水が生 起する場合をCase2 としている. 表-1 は実験条件を示し ているが, 実験ケースの最初の数字がCase1 と Case2 の 違いを示している. それぞれについて, 洗掘孔内に土砂を 充填していないケース (a) と充填しているが洗掘孔を メッシュで覆い土砂が抜け出さないようにしたケース (b), およびメッシュを取り除き洗掘孔内の土砂が実験開 始と同時に抜け出すようにしたケース(c)の3 種類の実験 を行った. 表中の2番目の数字がこれらの実験条件を示し ている. また, 3 番目の数字は, 同じ条件の実験を 2 度行っ ていることから 1,2 としている. c-3 5 (Case1-c-1,2 と Case1-c-4 およびCase2-c-1,2 とCase2-c-4 は，それぞれ 同じ条件の実験)では, 流量を $20,30,40(1 / \mathrm{s})$ と変えて洗 掘孔上部の流速および洗掘開始後 1 時間後 (洗掘が殆ど進 行しなくなった状況であり, 本研究ではこの状態を以下 最終洗掘深とする）の洗掘形状の計測を行った場合を示 している.

洗掘孔内の土砂が抜け出すケースの間隙水圧の計測は, 


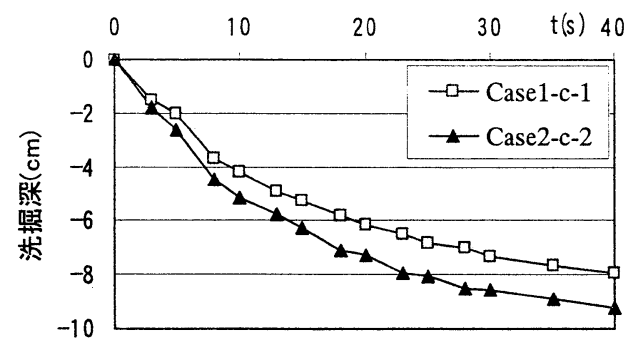

(a)洗掘孔の中心

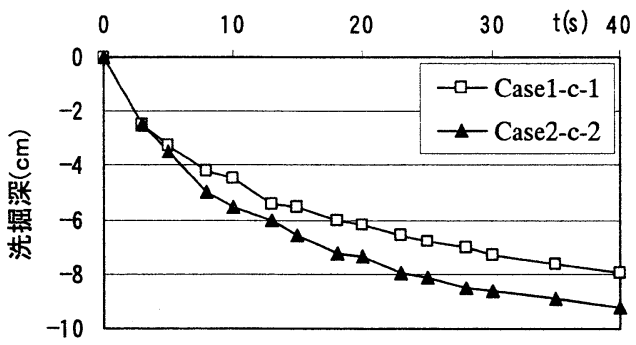

(b)洗掘孔中心より下流側 $1.5 \mathrm{~cm}$

図-2 洗掘の進行状況

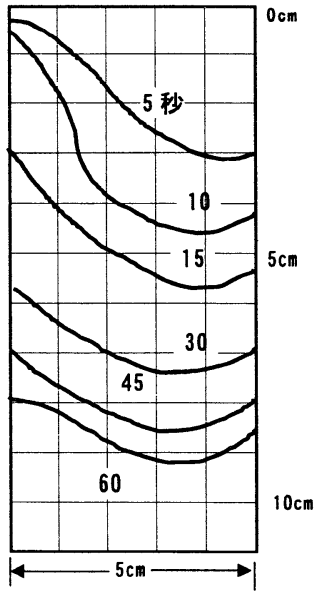

(a)Case1-c-1

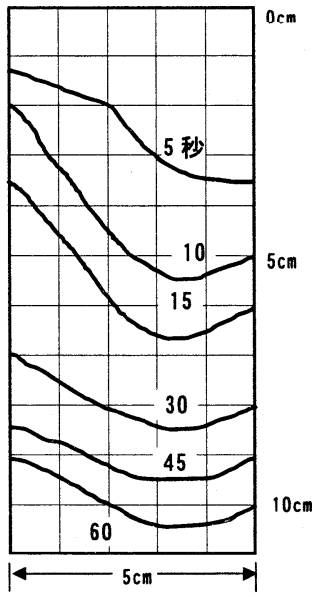

(b)Case2-c-2
図 -3: 洗掘の時間推移

洗掘孔内の土砂が流水により抜け出さないように, あら かじめ洗掘孔上にメッシュを敷き, 所定流況に達した後, 30 秒間経過した時点でメッシュを取り除く方法で行っ た.この実験の際には, 土砂の抜け出す様子もあわせてビ デオ撮影した. 洗掘が進行している時の洗掘孔内の流速 分布測定は困難であったため, 本研究ではCase1-c-1の20 秒程度洗掘が進行した時の洗掘孔内の河床形状を固定床 として設置し, その状態における洗掘孔内の流速分布を 計測した. 計測の際には一度に多点で流速計測可能なPIV 法によるビデオ画像解析を用いた. トレーサー粒子には, 直径が $1 \mathrm{~mm}$ の発砲スチロールビーズを用いた. 撮影には 高速度ビデオカメラを用い, 1 コマ $1 / 240$ 秒, シャッター 速度 $1 / 240$ 秒で撮影した.

\section{3. 実験結果および考察}

（1）洗掘の進行特性

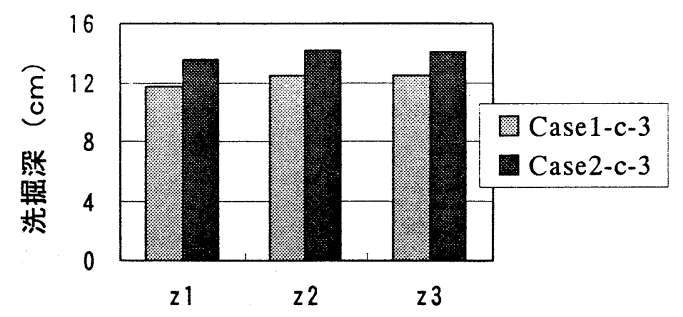

(a) 流量 $=20(\mathrm{l} / \mathrm{s})$

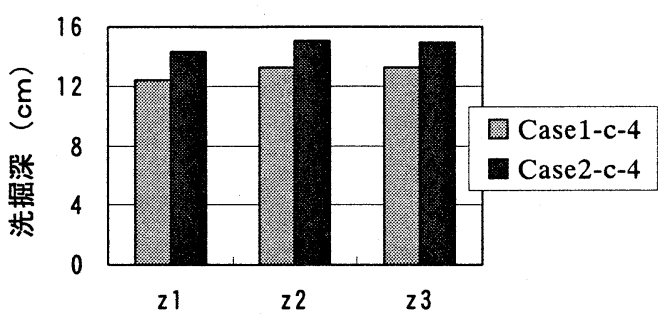

(b) 流量 $=30(1 / \mathrm{s})$

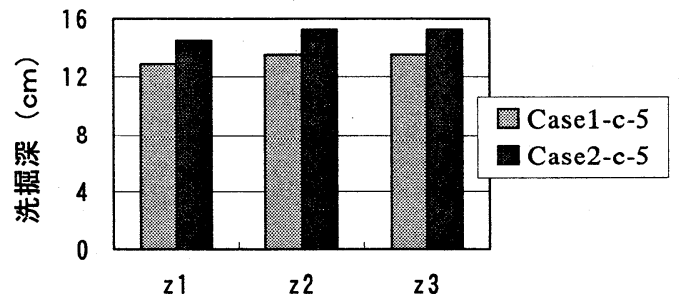

(c) 流量 $=40(\mathrm{l} / \mathrm{s})$

図 -4 最終洗掘深

図-2 は, 洗掘孔の中心位置と中心から下流側 $1.5 \mathrm{~cm}$ の 位置における洗掘の進行状況を示した図である. また, 図-3は, 土砂の抜け出し直後から60秒間の洗掘の推移を 示した図である. これらの図より, 洗掘は初期の段階で短 時間に進行し, 徐々に洗掘の進行の割合が小さくなるこ とがわかる. また, 洗掘開始後 15 秒程度までは, 洗掘孔 の下流側の洗掘深が最も大きく, 洗掘孔の上流側に向 かって洗掘深が小さくなることがわかる. これは, 洗掘開 始直後は洗掘孔下流部上端に衝突した流れが洗掘孔下降 に向かう噴流となるためであると考えられる. 洗掘開始 後20秒程度経過すると洗掘孔内には洗掘孔の水平距離と 同程度のスケールの渦が発生し, 最大洗掘深は洗掘孔の 下流部から洗掘孔の中心方向に移動する. また, 図-3に 示す実験開始後 30 秒 60 秒の洗掘形状より,このような 渦が発生した状況下においては, 洗掘の進行は洗掘孔内 でほぼ相似形を保ったまま進行することがわかる. 洗掘 上の跳水の有無についてみると, 洗掘孔上に跳水がある Case2-c-2の場合の方が洗掘の進行は早くなり, 60秒経過 した時点で約 $1.5 \mathrm{~cm}$ 程度洗掘深が大きくなっている.

\section{（2）最終洗掘梁の特性}

図-4の(a), (b), (c) は, 流量の違いによる洗掘開始後 1 時間後の最終洗掘深を示したもので, それぞれ流量を 20,30, 40 (1/s) とした場合である. 図中の z1 は洗掘孔の 中心より上流側 $1.5 \mathrm{~cm}, \mathrm{z} 2$ は洗掘孔の中心, $\mathrm{z} 3$ は洗掘孔の 


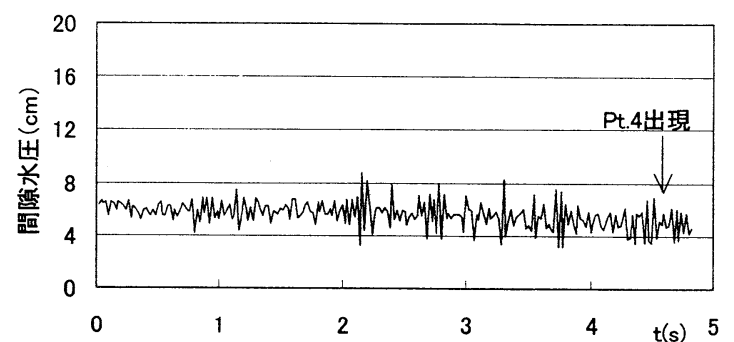

(a) Case1-c-1(跳水無·洗掘有)

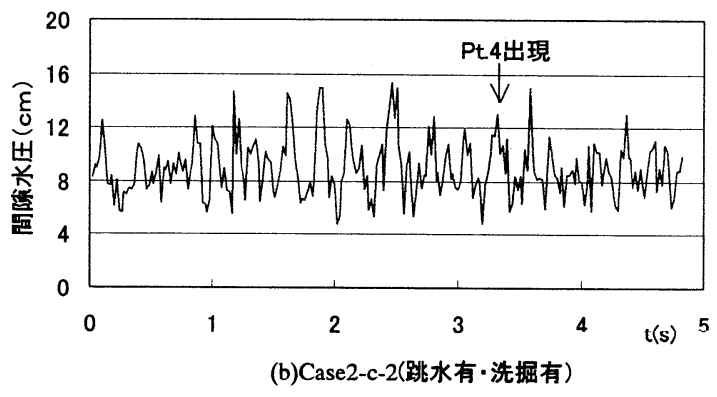

图 -5 間隙水圧の時間変化

中心より下流側 $1.5 \mathrm{~cm}$ の位置を示している. Case 1 と Case2での洗掘深を比較すると, 流量が20(1/s)の場合には Case2-c-3 の方が 10\% 程度, 流量 30, 40(1/s) の場合には Case2-c-4, Case2-c-5 の方が $11 \%$ 程度大きくなる. また, 流量による洗掘深の違いを比較すると, Case1シリーズで は, 流量が 30(1/s) のCase1-c-4 および40(1/s) のCase1-c5 は, 20(1/s) のCase1-c-3に比べ, $6 \%$ 程度および $9 \%$ 程度 大きい. Case2 シリーズでは, 流量が30(1/s) のCase2-c-4 および40(1/s)のCase2-c-5は, 20(1/s)のCase2-c-3に比べ, $5.5 \%$ 程度および $6.4 \%$ 程度大きい. 以上のことより, 流 量の大小に関わらず洗掘孔上の跳水の影響により洗掘梁 が $10 \%$ 程度大きくなることが明らかにされた.

\section{（3）間腺水圧の変動特性}

図-5(a), (b) は，それぞれCase1-c-1, Case2-c-2 の洗掘 が進行して土被り厚が少なくなり, Pt.4(図-1, 写真-2参 照)が現れる時間帯のPt.4の間隙水圧デー夕を表したもの である. Pt.4は, Case1-c-1 では4.7 秒後に, Case2-c-2で は3.3秒後に現れる. Case1-c-1についてみると, 2 秒程度 経過した時点で間隙水圧変動が大きくなっており，土砂 が抜け出して Pt.4 の土被り厚が減少すると, 間隙水圧の 変動が大きくなることがわかる. Case2-c-2 の場合にも 1 秒程度経過した時点から間隙水圧変動はやや大きくなっ ており,同様な傾向が見られる. 間隙水圧の変動は洗掘孔 上に跳水が有る場合の方が大きくなっており, 洗掘孔上 の跳水による水面変動が変動水圧として砂層に作用して いることがわかる(図-1 参照). 図-6 は, Case1-c-1 と Case2-c-2における土砂の抜け出し直後之土砂が抜け始め てから 80 秒後の間隙水圧の変動特性を示したもので, Pt.1 Pt.6 は洗掘孔内の測点, Pt.7 は洗掘孔の中心位置と 等しい水路中央部の河床面の測点である. この図より, Case1-c-1 は抜け出し 80 秒後の方がやや間隙水圧の変動 は大きくなるがその量は非常に小さい. 一方, Case2-c-2

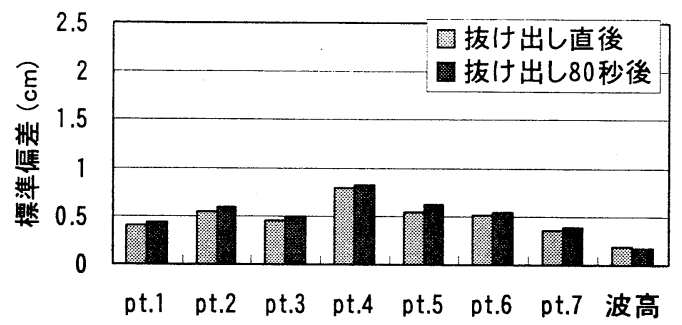

(a) Case1-c-1 (跳水無·洗掘有)

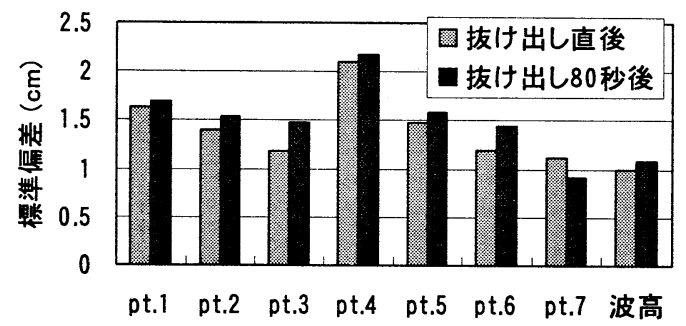

(b) Case2-c-2 (跳水有·洗掘有)

図 -6 間隙水圧の変動

では，抜け出し直後に比べ，土砂が抜け出してから 80 秒 後の方が間隙水圧の変動が大きくなっていることがわか る.これは, 実験開始直後の土砂が充填されている時には 砂層中で減衰していた間隙水圧が，土砂の抜出しが進む につれて土砂の影響を受けなくなり，洗掘孔内に直接水 圧が伝播するようになったためと考えられる. また, 洗掘 孔内の間隙水圧の変動は, 上流側, 下流側ともに河床に近 い測点Pt.1, Pt.4 の值が大きくなっている.これは, 洗掘 孔上部の乱れの影響が河床面に近いほど大きく, 深くな るほど弱まっていくためであると考えることができる. 水路中央部に位置する河床面の測点Pt.7 に比べ, 洗掘孔 内の方が間隙水圧の変動が大きくなっている.これは, 洗 掘孔の存在により洗掘孔上縁部と河床面との境で流水が 大きく乱されることが原因であると考えられる.

\section{（4）有效応力の变動特性}

図-7は, 土被り厚が減少してPt.1,Pt.4が現れる時間帯 の有効応力の変化を示している. この図より, Case1-c-1 では, 土被り厚が減少し Pt.1, Pt.4の出現が近づくにつれ て有効応力の変動が大きくなっていることがわかる. 洗 掘孔上に跳水があるCase2-c-2では, 実験初期の段階から 有効応力が急激に減少し, 変動もかなり大きくなってい る. また, Case1-c-1, Case2-c-2 ともにPt.1, Pt.4が出現す る前に有効応力が 0 となる液状化が発生しており, 砂粒子 が浮遊したような状況になっていることが予測される.

\section{（5）周波数特性}

表-2 は, Pt.1, Pt.4 の間隙水圧および水面変動(波高計) の周波数分析の結果を示したものである.この表より Case1シリーズでは卓越した周波数が存在していない.こ れは流れが射流であり，洗掘孔上で水面変動の乱れがほ とんど無かったことから卓越した周波数が存在しなかっ たと考えられる. また, 洗掘孔上に跳水がある Case2 シ 


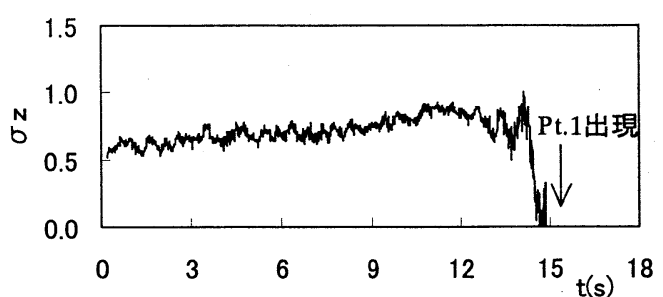

(a) Case1-c-1

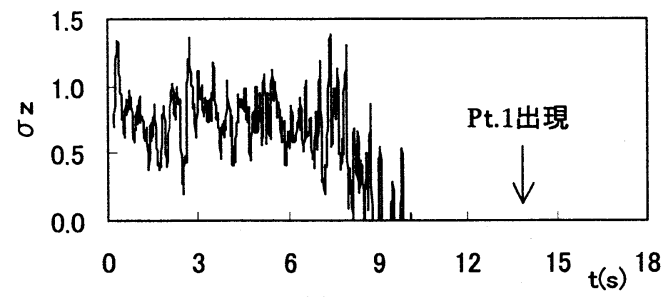

(b) Case2-c-2

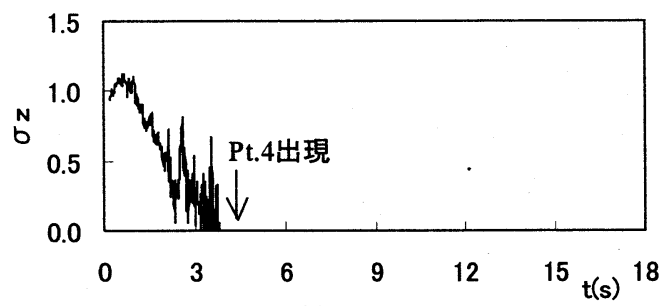

(c) Case1-c-1

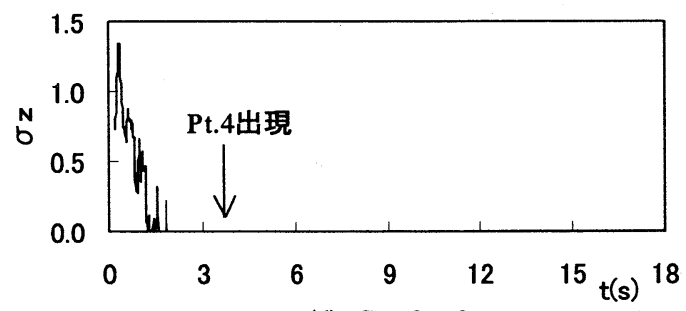

(d) Case2-c-2

图 -7 有効応力変化

リーズでは，3.0 4.0Hz の卓越周波数があることがわか る. 図-8 は Case2-c-2 の上流側の測点Pt.1, 下流側の測 点Pt.4, 波高計の卓越周波数特性を示した図である.

Pt.1, Pt.4 と波高計とのパワースペクトルが同様な変化傾 向を示すことがわかる. このことより水面変動と間隙水 圧変動とは密接な関係があることがわかる(図-1 参照).

\section{（6）跳水の有無による洗掘孔上の流速分布特性}

図-9は，洗掘孔の中心位置と等しい水路中央部の河床 面からの高さが $0.5 \mathrm{~cm}, 1.0 \mathrm{~cm}, 1.5 \mathrm{~cm}$ の流速を示したもの である. この図より, 洗掘孔上の流速は洗掘孔上に跳水が 無いCase1-c-1の方が速く, 13\%程度大きくなることがわ かる. このことより, 洗掘孔上に跳水がある Case2-c-2の 場合にはCase1-c-1よりも流速が遅いにも関わらず, 洗掘 深が大きくなったという実験結果を考慮すると, 洗掘孔 上に生起している跳水による水面変動が洗掘に大きな影 響を及ぼしていることがわかる.

\section{（7）洗掘孔内の流速分布特性}

図-10および図-11 は, Case1-c-1 およびCase2-c-2に
表 -2 卓越周波数

\begin{tabular}{|c|c|c|c|}
\hline Case & Pt.1 & Pt.4 & 波高計 \\
\hline $1-\mathrm{a}-1$ & - & - & - \\
\hline $1-\mathrm{a}-2$ & - & - & - \\
\hline $1-\mathrm{b}-1$ & - & - & - \\
\hline $1-\mathrm{b}-2$ & - & - & - \\
\hline $1-\mathrm{c}-1$ & - & - & - \\
\hline $1-\mathrm{c}-2$ & - & - & - \\
\hline $2-\mathrm{a}-1$ & $3.6 \mathrm{~Hz}$ & $3.7 \mathrm{~Hz}$ & $3.7 \mathrm{~Hz}$ \\
\hline $2-\mathrm{a}-2$ & $3.4 \mathrm{~Hz}$ & $3.4 \mathrm{~Hz}$ & $3.4 \mathrm{~Hz}$ \\
\hline $2-\mathrm{b}-1$ & $3.4 \mathrm{~Hz}$ & $3.4 \mathrm{~Hz}$ & $3.3 \mathrm{~Hz}$ \\
\hline $2-\mathrm{b}-2$ & $3.9 \mathrm{~Hz}$ & $3.9 \mathrm{~Hz}$ & $3.9 \mathrm{~Hz}$ \\
\hline $2-\mathrm{c}-1$ & $3.9 \mathrm{~Hz}$ & $3.9 \mathrm{~Hz}$ & $3.9 \mathrm{~Hz}$ \\
\hline $2-\mathrm{c}-2$ & $3.4 \mathrm{~Hz}$ & $3.4 \mathrm{~Hz}$ & $3.2 \mathrm{~Hz}$ \\
\hline
\end{tabular}

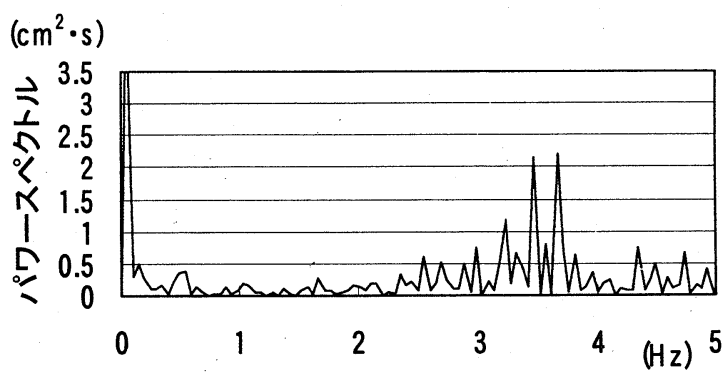

(a) Pt.1

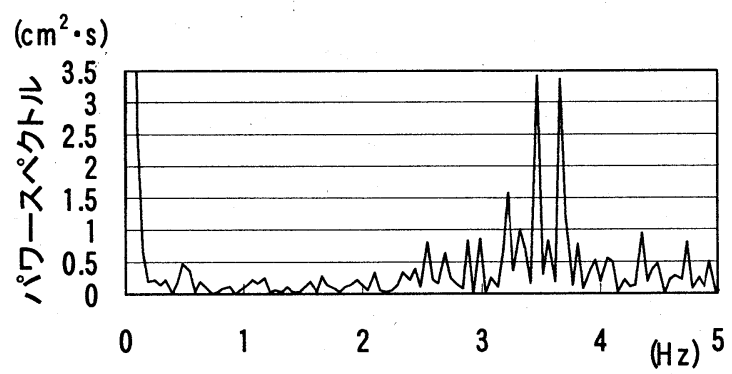

(b) Pt.4

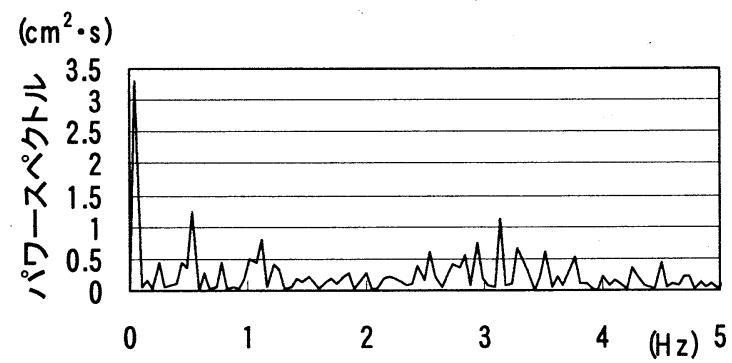

(c) 波高計

図-8 Case2-c-2 における周波数特性

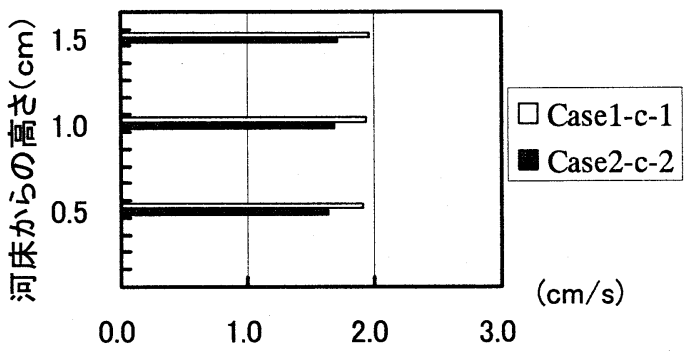

(a) 流量 $=30(1 / \mathrm{s})$

図 -9＼cjkstart堰下流部における流速分布特性 


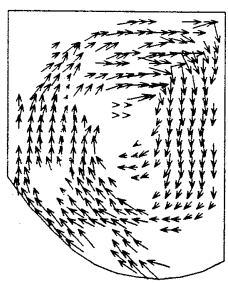

(a)

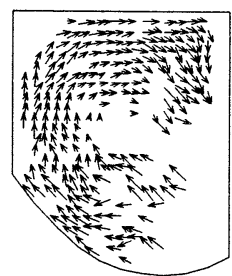

(a)

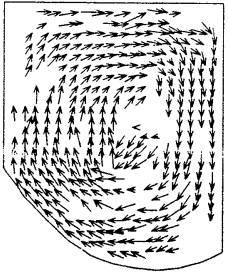

(b)

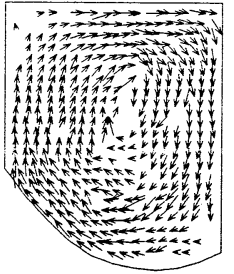

(c)

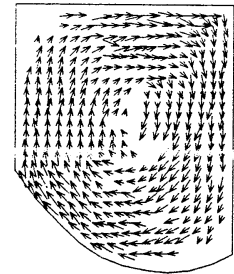

(d)

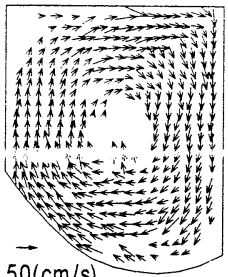

(e)

図-10 洗掘孔内の流速分布特性 (跳水無)

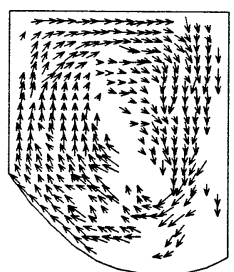

(b)

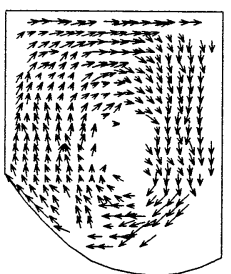

(c)

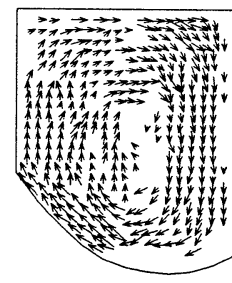

(d)

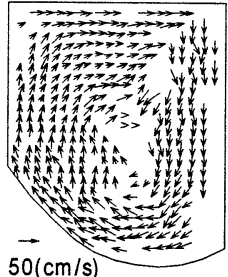

(e)

図-11 洗掘孔内の流速分布特性（跳水有）

おける洗掘孔内の流速分布を示したものである. 2章でも 述シたよに Case1-c-1の洗掘が20 秒程度進行した時 の洗掘孔内の河床形状を固定床として設置し，その状態 における洗掘孔内の流速分布を計測した. 図中の(a)〜(e) は, それぞれ連続した6コマの画像から流速分布を算出し ている. 図-10より, 洗掘孔内には時計回りの流れが発生 しすることがわかる. また, 渦の中心部はほぼ同じ位置に あり, 洗掘孔内の流れはかなり安定している. 一方, 図11 をみると, (a), (c), (e)に比べ(b), (d)の渦の中心位置が 下がっていることがわかる. これは, 跳水による水面変動 の影響により Case2-c-2 の洗掘孔内の流れが不安定とな るためである. この渦が上下する際には洗掘が急激に進 行することが実験中確認された.

\section{4. 結 論}

本研究では, 護床工からの土砂の抜け出しに及ぼす変 動水圧の影響を明らかにすることを目的として，洗掘孔 上における跳水の有無により変動水圧の影響を実験的に 検討した. その結果，以下のことが明らかにされた.

1) 洗掘孔上に跳水が生起している方が洗掘孔上の流速が 遅いにもかかわらず，洗掘の進行が早くなり，しかも 最終洗掘深も大きくなった.

2) 洗掘孔上に跳水が生起することにより, 洗掘孔内の流 れは不安定になる. 間隙水圧については，河床に近い 方が変動が大きく, 深くなるにつれて小さくなること が示された。

3) 洗掘孔内の間隙水圧の卓越周波数は水面変動の卓越周 波数と密接な関係があり, 跳水による水面変動が変動 水圧として洗掘孔に作用することが示された.

4) 洗掘は砂層表面付近の砂の液状化を伴いながら進行す ることが示された.
今後は，本研究で得られた成果をもとに洗掘孔内で発 生する渦の機構や洗掘に及ぼす変動水圧の影響をさらに 詳細に検討し, 変動水圧の影響を考慮した洗掘モデルを 確立するとともに，洗掘予測式や護床工の合理的な設計 指針を提示していく必要がある.

謝辞 : 本研究は日本学術振興会科学研究費の補助を得て 行われた. また, 画像解析にあたっては神戸大学の藤田一 郎先生より貴重な助言を得た. ここに記して感謝の意を 表する次第である.

\section{参考文献}

1) 鈴木幸一 : 円柱橋脚周辺の局所洗掘に関する研究，土木学会論 文集第313 号, pp.47-54, 1981.

2) 辻本哲朗, 水上敏昭: 円柱前面での局所洗据機構のモデル化, 第 29 回水理講演会論文集, pp.591-596, 1985.

3) 中川博次, 辻本哲郎, 清水義彦, 村上正吾 : 堰の被災機構とし ての護床工からの砂の抜け出しによる空洞化の進行過程, 第31 回水理講演会論文集, pp.359-364, 1987.

4) 神田敬一, 村本嘉雄, 藤田裕一郎 : 護床工の様式による下流部 局所洗据形状の相違，水工論文集，第36 巻, pp.43-48, 1992.

5) 名合宏之 : 砂層内水圧変動之液状化, 土木学会水理委員会, 水 工学シリーズ82-A-9, 1982.

6) 名合宏之, 前野詩朗 : 変動水圧作用下における護岸の裏込め土 砂の吸い出しに関する研究, 第32回水理講演会論文集, pp.595$600,1988$.

7) Maeno S. and Nago H. : Settlement of concrete block into a sand under water pressure variation, Proc. of SOWAS'88, pp.67-76, 1988.

8) Mia Md. F. and Nago H. : Effect of liquefaction on local scour around a circular bridge pier under sudden water pressure drop, Annual Journal of Hydraulic Engineering, JSCE, Vol.44, pp. 521-526, 2000.

9) 村上正吾, 辻本哲郎, 金崎伸夫, 萱島正友 : 透過性防護工の橋 脚周辺の局所洗掘に及ぼす影響について,水工学論文集第43巻, pp.629-634, 1999.

(2000. 10. 2受付) 